\title{
トリグリセリド油の混合エントロピー
}

\author{
丸銭 詔司 \\ 旭電化工業株式会社食品油脂研究所 (東京都荒川区東尾久 7-1)
}

\section{Entropy of Mixing of Triglycerides Oil}

\author{
Shouji MARUzenI \\ Food, Oil \& Fat Laboratories, Asahi Denka Co., Ltd. (7-1, Higashiogu, Arakawa-ku, Tokyo)
}

Using the model of the perfect solutions or the regular solutions, mathematical equations were derived for the approximation of the entropy of mixing of triglyceride oils, or fatty oil that is the solution of multicomponent of triglyceride species.

The molar entropy of mixing of triglyceride oils entirely depends upon the triglyceride structures; namely, the equations derived for mono acid structure $\left(s_{O}\right)$, 1-random-2-random-3-random $\left(s_{P}\right), 1,3$-random-2-random $\left(s_{Q}\right)$ and 1,2,3-random $\left(s_{R}\right)$ are respectively as follows;

$$
\begin{aligned}
& s_{O}=-R \sum_{J}^{n} w_{J} \ln w_{J} \\
& s_{P}=-R \sum_{i}^{3} \sum_{j}^{n} x_{J, i} \ln x_{J, i} \\
& s_{Q}=-R\left\{\sum_{j}^{n}\left(3 w_{J}-x_{J, 2}\right) \ln \left(\frac{3 w_{J}-x_{J, 2}}{2}\right)+\sum_{j}^{n} x_{J, 2} \ln x_{J, 2}\right\} \\
& s_{R}=-3 R \sum_{J}^{n} w_{J} \ln w_{J}
\end{aligned}
$$

where $R$ is the gas constant, $w_{J}$ and $x_{J, i}$ are mole fractions of acid radical $A_{J}(J=1,2, \cdots, n)$ in total fatty acid composition and in $i-(i=1,2,3)$ position respectively.

The increase of entropy of mixing and the free energy change as the regular solution in mixing of different kinds of triglyceride oils were also calculated by assuming that the structure of these oils is 1-random-2-random-3-random distribution.

\section{1 緒 言}

油脂の構成脂肪酸基が $n$ 種類であるとき, 単酸基トリ グリセリド構造 ${ }^{1}$ を仮定すると, $n$ 種類のトリグリセリ ドが存在することになる。しかし，このような単純な系 は, 合成, 混合された系以外には考えられず, 一般に は, 光学的立体異性体をも考慮して, $n^{3}$ 種類のトリグ リセリドの存在が想定され, 油脂の構成脂肪酸基の一般 的な種類の数を考慮するならば, 油脂がいかに複雑な混 合系であるかがわかる。

本報では，この複雑なトリグリセリド混合系としての 油脂の混合エントロピーを近似的に求めるアルゴリズム を示し，これにより，異なる油脂相互の混合エントロ ピーの比較, あるいは油脂と油脂とを混合したときの混 合エントロピー, 混合自由エネルギーの増分を求める。

\section{2 理論と考察}

トリグリセリド混合系としての 油脂の 混合エントロ
ピーを求めるためには, 油脂のトリグリセリド構造が知 られていなりればならないし, さらには, おのおののト リグリセリド成分の活量係数が求められていなければな らない。しかしながら, 非常に複雑な混合系であるがゆ えに, トリグリセリド構造を知ることは, 非常に困難な ことであり ${ }^{2)}$, また, おのおのの成分の活量係数を求め るといらことも同様である。

ここでは, トリグリセリド油の混合エントロピーの計 算式を, 次のような近似により導いた。i）トリグリセ リド混合系を, 完全溶液あるいは正則溶液と見なす。 ii）トリグリセリド構造を, 単酸基トリグリセリド構 造 ${ }^{1)}$, 1-random-2-random-3-random 分布構造 ${ }^{3)}, 1,3-$ random-2-random 分布構造 ${ }^{3}$ あるいは 1,2,3-random 分布構造 ${ }^{3)}$ で近似する。

ii）の近似トリグリセリド構造のなかで, 最もよい近 似は, 1-random-2-random-3-random 分布構造であ る。この分布構造を仮定し, 油脂と油脂との混合におけ る混合エントロピーおよび混合自由エネルギーの増分の 
計算法についても言及する。

\section{$2 \cdot 1$ 油脂の構造と混合エントロピー}

$N$ 種類のトリグリセリドの混合によるモル混合エン トロピー $s$ は, 完全溶液あるいは正則溶液近似で, 式 (1)のようになる。

$$
s=-R \sum_{i}^{N} X_{i} \ln X_{i}
$$

ここで, $R$ は気体定数, $X_{i}$ は $i$ 番目のトリグリセリド のモル分率である。式 (2) が明らかである。

$$
\sum_{i}^{N} X_{i}=1
$$

全ての成分について， $X_{i}$ が求まっている油脂の場合, トリグリセリド構造に関する近似を用いることなく, 式 （1）によって，モル混合エントロピーが計算される。し かしながら, 全ての成分について, $X_{i}$ が求まっている 油脂は皆無といってよく, 実際に式 (1) を計算するわけ にはいかないが以下に示すように, トリグリセリド構造 が仮定されさえすれば, トリグリセリド構造の近似の程 度に応じた近似值で, 混合エントロピーを求めることが できる。

油脂の構成脂肪酸基の種類の数を $n$ とする。Table1 に示すように, 構成脂肪酸基 $A_{J}(J=1,2, \cdots, n)$ の全 脂肪酸組成 $w_{J}$ および位置による脂肪酸分布組成 $x_{J, i}$ $(i=1,2,3)$ がそれぞれモル分率で求まっているものと する。次式が明らかである。

$$
\begin{aligned}
& \sum_{j}^{n} w_{J}=1 \\
& \sum_{J}^{n} x_{J, i}=1 \\
& w_{J}=\frac{1}{3} \sum_{i}^{3} x_{J, i}
\end{aligned}
$$

単酸基トリグリセリド構造を仮定した場合のトリグリ セリド油のモル混合エントロピー $s_{O}$ は, 全脂肪酸組成 のみで求められる(式 (6))。

$$
s_{O}=-R \sum_{J}^{n} w_{J} \ln w_{J}
$$

この場合, トリグリセリドの種類の数 $N$ と脂肪酸基の 種類の数 $n$ は等しくなる

1-random-2-random-3-random 分布構造を仮定した 場合のトリグリセリド油のモル混合エントロピー $s_{P}$ の 計算法を次に示す。この場合, 個々のトリグリセリドの モル分率は, 式 (7)

$$
\begin{aligned}
& \prod_{i}^{3}\left(\sum_{J}^{n} x_{J, i}\right)=\left(x_{1,1}+\cdots+x_{n, 1}\right) \\
& \quad \times\left(x_{1,2}+\cdots+x_{n, 2}\right)\left(x_{1,8}+\cdots+x_{n, 8}\right)
\end{aligned}
$$

の展開式 (8)

$$
=x_{1,1} x_{1,2} x_{1,8}+\cdots+x_{I, 1} x_{J, 2} x_{K, 8}+\cdots+x_{n, 1} x_{n, 2} x_{n, 8}
$$

の各項で表せる。つまり，1，2 および 3 位置に, それ ぞれ脂肪酸基 $A_{I}, A_{J}$ および $A_{K}$ がついているトリグ
Table-1 Total and positional fatty acids composition in triglycerides.

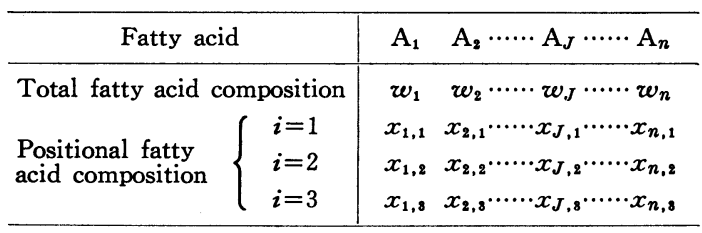

リセリドのモル分率は， $x_{I, 1} x_{J, 2} x_{K, 3}$ となる。この場 合, $N$ は式 (8) の項の数に等しいから, $n^{3}$ となる。以 上のことより， $s_{P}$ は, 式 (9) で表せる。

$$
s_{P}=-R \sum_{I, J, K}^{n} x_{I, 1} x_{J, 2} x_{K}, \ln \left(x_{I, 1} x_{J, 2} x_{K, 8}\right)
$$

式 (9) で，直接 $s_{P}$ を計算することは，不可能ではない が, 非常にめんどうである。容易に計算できるように変 形する。式 (9) は次のように変形できる。

$$
\begin{aligned}
s_{P}= & -R \sum_{I, J, K}^{n}\left\{\left(x_{I, 1} x_{J, 2} x_{K, 8} \ln x_{I, 1}\right)\right. \\
& \left.+\left(x_{I, 1} x_{J, 2} x_{K, 8} \ln x_{J, 2}\right)+\left(x_{I, 1} x_{J, 2} x_{K, 8} \ln x_{K, 8}\right)\right\}
\end{aligned}
$$

ここで, $\eta_{I, 1}=x_{I, 1} \ln x_{I, 1}, \eta_{J, 2}=x_{J, 2} \ln x_{J, 2}$ および $\eta_{K, 3}=x_{K, 3} \ln x_{K, 3}$ とおくと, 式（10）は, 次のように 変形でき,

$$
\begin{aligned}
-\frac{s_{P}}{R}= & \sum_{I, J, K}^{n}\left\{\eta_{I, 1} x_{J, 2} x_{K, 8}+x_{I, 1} \eta_{J, 2} x_{K, 8}+x_{I, 1} x_{J, 2} \eta_{K, 8}\right\} \\
= & \sum_{I, J, K}^{n} \eta_{I, 1} x_{J, 2} x_{K, 8}+\sum_{I, J, K}^{n} x_{I, 1} \eta_{J, 2} x_{K, 8} \\
& +\sum_{I, J, K}^{n} x_{I, 1} x_{J, 2} \eta_{K, 8} \\
= & \left(\sum_{I}^{n} \eta_{I, 1}\right)\left(\sum_{J}^{n} x_{J, 2}\right)\left(\sum_{K}^{n} x_{K, 8}\right) \\
& +\left(\sum_{I}^{n} x_{I, 1}\right)\left(\sum_{J}^{n} \eta_{J, 2}\right)\left(\sum_{K}^{n} x_{K, 8}\right) \\
& +\left(\sum_{I}^{n} x_{I, 1}\right)\left(\sum_{j}^{n} x_{J, 2}\right)\left(\sum_{K}^{n} \eta_{K, 8}\right)
\end{aligned}
$$

式（11）のようになる。ここで, 式（4）の関係を用い ると, 式 (12) が得られ,

$$
s_{P}=-R\left\{\sum_{I}^{n} \eta_{I, 1}+\sum_{J}^{n} \eta_{J, 2}+\sum_{K}^{n} \eta_{K, 3}\right\}
$$

結局, $s_{P}$ は, 式 (13) で求めることができる。

$$
s_{P}=-R \sum_{i}^{3} \sum_{j}^{n} x_{J, i} \ln x_{J, i}
$$

1-random-2-random-3-random 分布構造より,さら にあらい近似として，1,3-random-2-random 分布構造 という考え方もある。1,3-random-2-random 分布構造 とは, 1-random-2-random-3-random 分布構造におい て, 1 位置と 3 位置の脂肪酸組成が同一 $\left(x_{J, 1}=x_{J, 3}\right)$ であると考える近似トリグリセリド構造である。もし， 1-random-2-random-3-random 分布構造のトリグリセ リド油の 1 位置と 3 位置のみの脂肪酸基がランダムに 再配置されるならば, 1,3-random-2-random 分布構造 のトリグリセリド油となるであろう。1,3-random-2- 
random 分布構造に 対応するモル混合エントロピー $s_{Q}$ は, 式 (13) において,

$$
x_{J, 1}=x_{J, 8}=u_{J}
$$

とおいた式

$$
s_{Q}=-R\left\{2 \sum_{J}^{n} u_{J} \ln u_{J}+\sum_{J}^{n} x_{J, 2} \ln x_{J, 2}\right\}
$$

で表せる。式 (5)，(14)より

$$
u_{J}=\frac{3 w_{J}-x_{J, 2}}{2}
$$

だから, $s_{Q}$ は, 全脂肪酸組成と 2 位置の脂肪酸組成よ り計算できる(式 (17))。

$$
\begin{aligned}
s_{Q}= & -R\left\{\sum_{J}^{n}\left(3 w_{J}-x_{J, 2}\right) \ln \left(\frac{3 w_{J}-x_{J, 2}}{2}\right)\right. \\
& \left.+\sum_{J}^{n} x_{J, 2} \ln x_{J, 2}\right\}
\end{aligned}
$$

1,2,3-random 分布構造は, 1,3-random-2-random 分布構造より,さらにあらい近似トリグリセリド構造で ある。1,2,3-random 分布構造に対応するトリグリセリ ド油のモル混合エントロピー $s_{R}$ は, 式 (13) におい $\tau$,

$$
x_{J, 1}=x_{J, 2}=x_{J, 8}=w_{J}
$$

とおいた式

$$
s_{R}=-3 R \sum_{J}^{n} w_{J} \ln w_{J}
$$

で求めることができる。エステル交換反応などにより， 1,2,3-random 分布構造となった油脂のモル混合エント ロピーは, 式 (19) で表せる。

ある一つのトリグリセリド油に対する近似 モル混合 エントロピー $s$ (式 (1)), $s_{O}$ (式 (6)), $s_{P}$ (式 (13)), $s_{Q}$ (式 (15) あるいは式 (17)) および $s_{R}$ (式 (19)) の 間には, 式 (20)，(21）の関係が成立し (Appendix 参 照),

$$
\begin{aligned}
& \frac{s_{R}}{s_{O}}=3 \\
& s_{O} \leqq s \leqq s_{P} \leqq s_{Q} \leqq s_{R}
\end{aligned}
$$

\begin{tabular}{|c|c|c|c|c|c|c|c|c|c|c|c|c|}
\hline \multirow{2}{*}{ Oil } & \multirow{2}{*}{ Position } & \multicolumn{11}{|c|}{ Fatty acid } \\
\hline & & $16: 0$ & $16: 1$ & $18: 0$ & $18: 1$ & $18: 2$ & $18: 3$ & $20: 0$ & $20: 1$ & $22: 0$ & $22: 1$ & $24: 0$ \\
\hline \multirow{4}{*}{ Peanut } & & \multicolumn{11}{|c|}{ (mole fraction) $\times 100$} \\
\hline & 1 & 13.6 & 0.3 & 4.6 & 59.2 & 18.5 & & 0.7 & $1.1^{*}$ & 1.3 & & 0.7 \\
\hline & 2 & 1.6 & 0.1 & 0.3 & 58.5 & 38.6 & & - & $0.3^{*}$ & 0.2 & & 0.5 \\
\hline & 3 & 11.0 & 0.3 & 5.1 & 57.3 & 10.0 & & 4.0 & $2.7^{*}$ & 5.7 & & 2.8 \\
\hline \multirow{3}{*}{ Rapeseed } & 1 & 4.1 & 0.3 & 2.2 & 23.1 & 11.1 & 6.4 & & 16.4 & 1.4 & 34.9 & \\
\hline & 2 & 0.6 & 0.2 & - & 37.3 & 36.1 & 20.3 & & 2.0 & - & 3.6 & \\
\hline & 3 & 4.3 & 0.3 & 3.0 & 16.6 & 4.0 & 2.6 & & 17.3 & 1.2 & 51.0 & \\
\hline \multirow{3}{*}{ Soybean } & 1 & 13.8 & & 5.9 & 22.9 & 48.4 & 9.1 & & & & & \\
\hline & 2 & 0.9 & & 0.3 & 21.5 & 69.7 & 7.1 & & & & & \\
\hline & 3 & 13.1 & & 5.6 & 28.0 & 45.2 & 8.4 & & & & & \\
\hline \multirow{3}{*}{ Linseed } & 1 & 10.1 & 0.2 & 5.6 & 15.3 & 15.6 & 53.2 & & & & & \\
\hline & 2 & 1.6 & 0.1 & 0.7 & 16.3 & 21.3 & 59.8 & & & & & \\
\hline & 3 & 6.0 & 0.3 & 4.0 & 17.0 & 13.2 & 59.4 & & & & & \\
\hline \multirow{3}{*}{ Corn } & 1 & 17.9 & 0.3 & 3.2 & 27.5 & 49.8 & 1.2 & & & & & \\
\hline & 2 & 2.3 & 0.1 & 0.2 & 26.5 & 70.3 & 0.7 & & & & & \\
\hline & 3 & 13.5 & 0.1 & 2.8 & 30.6 & 51.6 & 1.0 & & & & & \\
\hline \multirow{3}{*}{ Olive } & 1 & 13.1 & 0.9 & 2.6 & 71.8 & 9.8 & 0.6 & & & & & \\
\hline & 2 & 1.4 & 0.7 & - & 82.9 & 14.0 & 0.8 & & & & & \\
\hline & 3 & 16.9 & 0.8 & 4.2 & 73.9 & 5.1 & 1.3 & & & & & \\
\hline \multirow{3}{*}{ Cacao butter } & 1 & 34.0 & 0.6 & 50.4 & 12.3 & 1.3 & & 1.0 & & & & \\
\hline & 2 & 1.7 & 0.2 & 2.1 & 87.4 & 8.6 & & 0.0 & & & & \\
\hline & 3 & 36.5 & 0.3 & 52.8 & 8.6 & 0.4 & & 2.3 & & & & \\
\hline \multirow{3}{*}{$\begin{array}{l}\text { Randomized } \\
\text { soybean }\end{array}$} & 1 & 9.5 & & 4.2 & 23.6 & 54.9 & 7.8 & & & & & \\
\hline & 2 & 11.1 & & 4.4 & 23.3 & 52.9 & 8.3 & & & & & \\
\hline & 3 & 10.6 & & 4.6 & 25.1 & 51.2 & 8.5 & & & & & \\
\hline
\end{tabular}

したがって, 式 (22) が明らかである。

$$
1 \leqq \frac{s}{s_{O}} \leqq \frac{s_{P}}{s_{O}} \leqq \frac{s_{Q}}{s_{O}} \leqq 3
$$

\section{$2 \cdot 2$ 混合エントロピーの比較}

異なる油脂相互の混合エントロピーの比較は, モル混 合エントロピーの近似值 $s, s_{P}$ あるいは $s_{Q}$ で直接比較

Table-2 Positional distribution of fatty acid in triglycerides of vegetable oils by Brockerhoff and Yurkowskis).

\footnotetext{
* Together with $18: 3$.
} 
Table-3 $s_{P} / s_{O}$ and $s_{Q} / s_{O}$ of vegetable oils.

\begin{tabular}{|c|c|c|c|c|c|}
\hline \multirow{2}{*}{ Oil } & $s_{O}$ & $s_{P}$ & $s_{Q}$ & $s_{P} / s_{O}$ & $s_{Q} / s_{O}$ \\
\hline & \multicolumn{3}{|c|}{$\left(\mathrm{cal} \cdot{ }^{\circ} \mathrm{K}^{-1} \cdot \mathrm{mole}^{-1}\right)$} & \multicolumn{2}{|c|}{$(\longrightarrow)$} \\
\hline Peanut & 2.506 & 6.969 & 7.074 & 2.782 & 2.823 \\
\hline Rapeseed & 3.428 & 8.930 & 9.025 & 2.606 & 2.633 \\
\hline Soybean & 2.438 & 7.011 & 7.017 & 2.875 & 2.878 \\
\hline Linseed & 2.399 & 7.059 & 7.077 & 2.942 & 2.950 \\
\hline Corn & 2.102 & 6.079 & 6.087 & 2.892 & 2.896 \\
\hline Olive & 1.661 & 4.706 & 4.731 & 2.833 & 2.848 \\
\hline Cacao butter & 2.512 & 5.240 & 5.259 & 2.086 & 2.094 \\
\hline Randomized Soybean & 2.498 & 7.490 & 7.492 & 2.998 & 2.999 \\
\hline
\end{tabular}

できる。しかし，これらの值は，全脂肪酸組成が異なる と, とり得る值の範囲が異なってくる。与えられた全脂 肪酸組成の範囲内で, どの程度乱雑にトリグリセリドが 合成されているかを示寸標準的な 尺度として， $s_{/} / s_{O}$ が 考えられる。この值は, 全てのトリグリセリド油に対し て, 単酸基トリグリセリド構造の場合, 1 となり, 最も 乱雑な構造である 1,2,3-random 分布構造の場合, 最 大值 3 となる (式 $(22)) 。 s / s_{O}$ の值を求めるわけにはい かないので,ここでは, $s_{P} / s_{O}$ あるいは $s_{Q} / s_{O}$ で比較す ることにする。全ての油脂のトリグリセリド構造が, 1randm-2-random-3-random 分布に従うという保証は ないが, ある種の油脂のトリグリセリド構造は, この分 布計算值とよい一致を示すことが確かめられている4)。 また, Brockerhoff ら ${ }^{5)}$ は,この分布計算法により, 光学 的に活性なトリグリセリド成分の推定を行っている。比

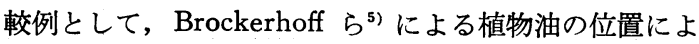
る脂肪酸分布組成の 分析值 (Table-2) により, $s_{P} / s_{O}$ および $s_{Q} / s_{O}$ を計算し, Table-3 に示した。ただし, $s_{O}$ および $s_{Q}$ は, 式 (5) により, 全脂肪酸組成を求め て計算した。

これらのトリグリセリド油の混合エントロピーの大き さの順序は, Table-3 に見るように, $s_{P}$ で比較すると， オリブ油くカカオ脂くとうもろこし油＜落花生油＜大豆 油くあまに油くランダム化大豆油くなたね油，となり， $s_{Q}$ で比較すると，オリブ油<カカオ脂 $<$ とうもろこし 油＜大豆油＜落花生油＜あまに油＜ランダム化大豆油＜ なたね油，となる。 $s_{P} / s_{O}$ および $s_{Q} / s_{O}$ による比較で は, カカオ脂くなたね油＜落花生油＜オリブ油<大豆油 くとうもろこし油くあまに油＜ランダム化大豆油，とな る。ランダム化大豆油の $s_{P} / s_{O}$ あるいは $s_{Q} / s_{O}$ は, 当 然のことながら， 3 に非常に近い值をとっている。

\section{$2 \cdot 3$ 油脂の混合による混合エントロピーの増分}

油脂のトリグリセリド構造が, 1-random-2-random3-random 分布に従うといら仮定のもとで, 油脂と油脂 の混合における混合エントロピーの増分を次に求める。

油脂 $\mathrm{A}$ と油脂 $\mathrm{B}$ を，それぞれモル分率 $X^{A}$ および $X^{B}$ で混合すると, 混合油脂 $\mathrm{M}$ の位置による脂肪酸分布組
成 $x_{J, i}{ }^{M}$ は, 1-random-2-random-3-random 分布仮 定より, 式 (23) で表せる。

$$
\begin{aligned}
& x_{J, i}{ }^{M}=x_{J, i}{ }^{A} X^{A}+x_{J, i}{ }^{B} X^{B} \\
& X^{A}+X^{B}=1
\end{aligned}
$$

ここで, $x_{J, i}{ }^{A}$ および $x_{J, i}{ }^{B}$ は, それぞれ油脂Aおよ び油脂 $\mathrm{B}$ の位置による脂肪酸分布組成である。したがっ て, 混合油脂Mのモル混合エントロピーは, 1-random2-random-3-random 分布構造の場合（式 (13)）と同 様に求められ，これを $s_{P}{ }^{M}$ とすると，

$$
s_{P}{ }^{M}=-R \sum_{i}^{3} \sum_{J}^{n} x_{J, i}{ }^{M} \ln x_{J, i}{ }^{M}
$$

となる。混合によるモル混合エントロピーの増分 $\Delta s_{P}{ }^{\mathrm{Mix}}$ は, 式 (26) で表せる。

$$
\Delta_{s_{P}}{ }^{\mathrm{Mix}}=s_{P}{ }^{M}-s_{P}{ }^{A} X^{A}-s_{P}{ }^{B} X^{B}
$$

ここで, $s_{P}{ }^{A}$ および $s_{P}{ }^{B}$ は, 油脂Aおよび油脂 $\mathrm{B} の モ$ ル混合エントロピーで, 式 (13) により求められるもの である。なたね油 (A) と大豆油 (B) を混合したとき の $\Delta s_{P}{ }^{\text {Mix }}$ を Table-2, Table-3 の数值を用い, 式 （26）で計算した結果を Table-4 に示した。また，他の 油脂の組み合わせによる混合の場合の $\Delta_{s P}^{\mathrm{Mix}}$ を同様にし て求め, Fig.-1 に示した。Fig.-1 に見るように, 位置 による脂肪酸分布組成が類似している大豆油ととうもろ こし油の $\Delta s_{P}{ }^{\mathrm{Mix}}$ は, 他の組み合わせによるそれより も，非常に小さいことがわかる。

\section{4 油脂の混合による混合自由エネルギー}

草野 ${ }^{6}$ は, 油脂と油脂との混合に伴う容積変化と混合

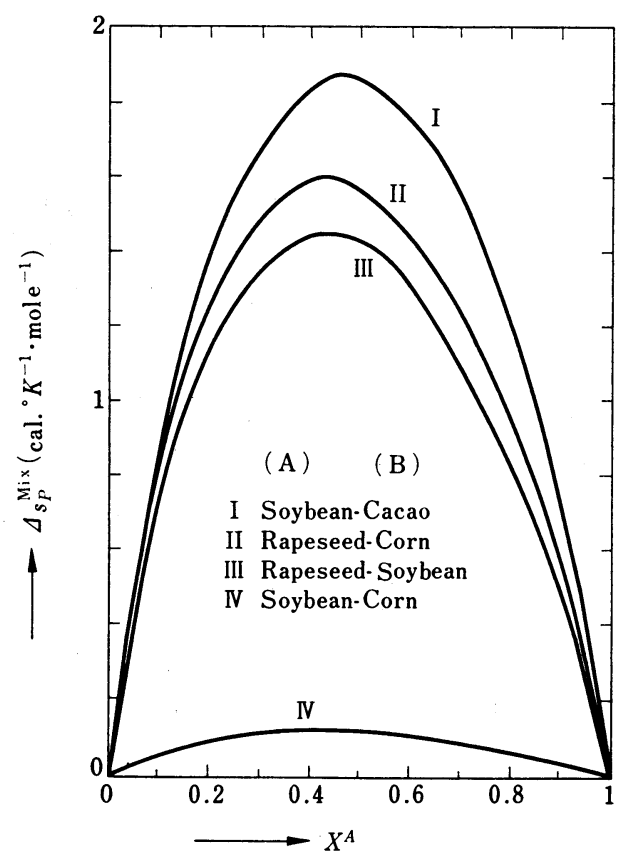

Fig.-1 Increase of molar entropy of mixing; $\Delta s_{P^{\mathrm{Mix}}}$ as a function of mole fraction $X^{A}$. 
Table-4 Increase of molar entropy of mixing; $\Delta s_{P^{\mathrm{Mix}}}$ in mixing of rapeseed oil (A) and soybean oil (B).

\begin{tabular}{c|c|c|c|c}
\hline \multirow{2}{*}{$X^{A}$} & \multirow{2}{*}{$s_{P}{ }^{M}$} & $s_{P}{ }^{A} X^{A}$ & $s_{P}{ }^{B} X^{B}$ & $\Delta_{S_{P}{ }^{\mathrm{Mix}}}$ \\
\cline { 3 - 5 } & & \multicolumn{3}{|c}{$\left(\mathrm{cal} \cdot{ }^{\circ} \mathrm{K}^{-1} \cdot \mathrm{mole}^{-1}\right)$} \\
\hline 0.0000 & 7.011 & 0.000 & 7.011 & 0.000 \\
0.1192 & 8.085 & 1.065 & 6.175 & 0.845 \\
0.2273 & 8.649 & 2.030 & 5.417 & 1.202 \\
0.3698 & 9.135 & 3.303 & 4.418 & 1.415 \\
0.5807 & 9.470 & 5.187 & 2.940 & 1.343 \\
0.7259 & 9.472 & 6.483 & 1.922 & 1.067 \\
0.8767 & 9.273 & 7.830 & 0.864 & 0.579 \\
1.0000 & 8.930 & 8.930 & 0.000 & 0.000 \\
\hline
\end{tabular}

熱の精密な測定を行い, 一般に, 容積は，わずかに膨張 し，かつ吸熱することを見いだしている。この混合油脂 系の容積変化は, 非常に小さいから, これによるエネル ギー変化量を無視し，正則溶液として取り扱うことがで きる ${ }^{6)}$ 。正則溶液が, 定温, 定圧でつくられるときのモ ル混合自由エネルギー $g^{M}$ は, 熱力学によると, 式 (27）で表される ${ }^{7)}$ 。

$$
g^{M}=h^{E}-T s^{M}
$$

ここで, $h^{E}$ はモル剩余エンタルピー (混合熱), $s^{M}$ は モル混合エントロピーで，完全溶液のそれで 表され， 油脂と油脂との混合におけるそれは, 前節で求めた $\Delta s_{P}{ }^{\mathrm{Mix}}$ で近似できる。草野 ${ }^{6}$ による，大気圧下， 303.15 ${ }^{\circ} \mathrm{K}$ におけるなたね油 と大豆油の混合熱の測定值を $h^{E}$ とし, Table-4 における $\Delta s_{P}{ }^{\mathrm{Mix}}$ を $s^{M}$ として, 大気 圧下， $303.15^{\circ} \mathrm{K}$ におけるなたね油と大豆油の混合に伴 5自由エネルギー変化 $\left(g^{M}\right)$ を式 $(27)$ によって計算 し, Table-5 および Fig.-2 に示した。この近似計算 結果から見ると，なたね油と大豆油の混合における自由 エネルギー変化に大きく寄与するのは, エントロピー項 であって，エネルギー項の寄与は非常に小さいというこ とである。 $g^{M}$ が最小值をとる $X^{A}=0.45$ においては， $g^{M}$ に占める $h^{E}$ の割合は，約 6(\%) にすぎない。お そらく, 他の油脂と油脂との組み合わせによる混合過程 も，ほとんどェントロピー的に行われるものと推定でき る。

Table-5 Molar free energy of mixing; $g^{M}$ in mixing of rapeseed oil (A) and soybean oil (B) at $303.15^{\circ} \mathrm{K}$.

\begin{tabular}{c|c|c|c}
\hline \multirow{2}{*}{$X^{A}$} & $h^{\left.E_{6}\right)}$ & $T \Delta_{s_{P}^{\mathrm{Mix}}}$ & $g^{M}$ \\
\cline { 2 - 4 } & \multicolumn{3}{|c}{$\left(\mathrm{cal} \cdot \mathrm{mole}^{-1}\right)$} \\
\hline 0.1192 & +11.9 & +256.2 & -244.3 \\
0.2273 & +20.1 & +364.4 & -344.3 \\
0.3698 & +25.2 & +429.0 & -403.8 \\
0.5807 & +26.2 & +407.1 & -380.9 \\
0.7259 & +22.0 & +323.5 & -301.5 \\
0.8767 & +11.7 & +175.5 & -163.8 \\
\hline
\end{tabular}

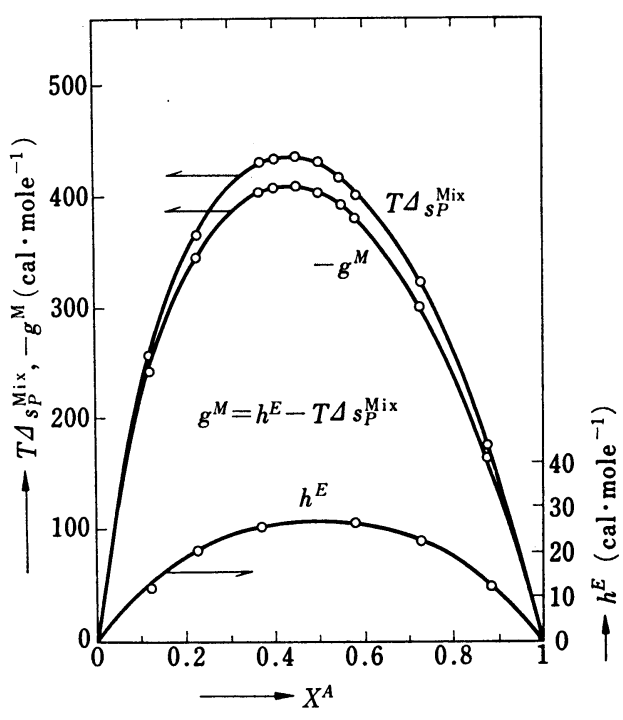

Fig.-2 Molar free energy of mixing; $\boldsymbol{g}^{\boldsymbol{M}}$ in mixing of rapeseed oil (A) and soybean oil (B) at $303.15^{\circ} \mathrm{K}$.

草野 ${ }^{8), 9)}$ は, 油脂と溶媒の混合における混合熱, 混合 エントロピーなどの測定を行い, 混合自由エネルギーに 大きく寄与するのは, 混合エントロピー項であって, エ ネルギー項は小さいといら, 上述の結果と同様の結果を 得ているが, これらの結果は, 油脂の非常に複雑なトリ グリセリド構造を反映しているものと考えられる。

\section{Appendix}

不等式 (21) について, 補足説明する。 $s_{O} \leqq s$ は明ら かであろう。また， $s_{P}, s_{Q}$ および $s_{R}$ は，いずれも， ンダム状態を仮定することによって近似したトリグリセ リド構造 ${ }^{3}$ に対応しており，これらは，トリグリセリド 構造に対して，何ら近似を施さない場合のモル混合エン トロピー $s$ より大きくなる。

$$
s_{O} \leqq s \leqq s_{P}, s_{Q}, s_{R}
$$

次に, $s_{P} \leqq s_{Q}$ の証明を行う。式 (13) と式 (15) の 差をとり変型すると, 式 (A.1) のよ5になる。

$$
\begin{aligned}
& -\frac{\left(s_{P}-s_{Q}\right)}{R}=\sum_{J}^{n} \Delta_{J} \\
& \Delta_{J}=x_{J, 1} \ln x_{J, 1}+x_{J, 8} \ln x_{J, 8}-2 u_{J} \ln u_{J}
\end{aligned}
$$

また, $u_{J}$ は, $x_{J, 1}$ と $x_{J, 3}$ の平均値に等しい。

$$
u_{J}=\left(x_{J, 1}+x_{J, 8}\right) / 2
$$

$x_{J, 3} \geqq x_{J, 1}(>0)$ の場合を先ず考える。このとき，

$$
\left.\begin{array}{rl}
x_{J, 1} & =u_{J}-\delta_{J} \\
x_{J, 3} & =u_{J}+\delta_{J} \\
\delta_{J} & \geqq 0
\end{array}\right\}
$$

を満足する $\delta_{J}$ が存在し, 式 (A.2), (A.3) より, 式 (A.4)

$$
\begin{aligned}
\Delta_{J}= & \Delta_{J}\left(\delta_{J}\right)=\left(u_{J}-\delta_{J}\right) \ln \left(u_{J}-\delta_{J}\right) \\
& +\left(u_{J}+\delta_{J}\right) \ln \left(u_{J}+\delta_{J}\right)-2 u_{J} \ln u_{J}
\end{aligned}
$$


を得る。

$$
\frac{d}{d \delta_{J}} \Delta_{J}\left(\delta_{J}\right)=\ln \left(\frac{u_{J}+\delta_{J}}{u_{J}-\delta_{J}}\right) \geqq 0 \quad\left(\because \delta_{J} \geqq 0\right)
$$

したがって, $\Delta_{J}\left(\delta_{J}\right)$ は増加関数で, かつ, $\Delta_{J}(0)=0$ と なる。ゆえに, $\Delta_{J} \geqq 0$ となる。 $x_{J, 1} \geqq x_{J, 3}(>0)$ の場 合,

$$
\left.\begin{array}{c}
x_{J, 1}=u_{J}+\delta_{J} \\
x_{J, s}=u_{J}-\delta_{J} \\
\delta_{J} \geqq 0
\end{array}\right\}
$$

を満足する $\delta_{J}$ が存在し, 式 (A.2), (A.3') 上り式 (A.4) を得る。したがって, $\Delta_{J} \geqq 0$ となる。以上よ $\eta, x_{J, 1} \lesssim x_{J, 3}$ で $\Delta_{J} \geqq 0$ となり, 次式を得る。

$$
-\frac{\left(s_{P}-s_{Q}\right)}{R}=\sum_{j}^{n} \Delta_{J} \geqq 0
$$

$$
\therefore s_{P} \leqq s_{Q}
$$

等号が成立するのは, $x_{J, 1}=x_{J, 3}$ のときである。

次に, $s_{Q} \leqq s_{R}$ の証明を行う。式 (15) と式 (19) の 差をとり, 変形すると, 式 (A.5) のようになる。

$$
\begin{aligned}
& -\frac{\left(s_{Q}-s_{R}\right)}{R}=\sum_{J}^{n} \Delta_{J} \\
& \Delta_{J}=2 u_{J} \ln u_{J}+x_{J, 2} \ln x_{J, 2}-3 w_{J} \ln w_{J}
\end{aligned}
$$

また，次式が明らかである。

$$
w_{J}=\left(2 u_{J}+x_{J, 2}\right) / 3
$$

$x_{J, 2} \geqq u_{J}(>0)$ の場合を先ず考える。このとき，

$$
\left.\begin{array}{c}
u_{J}=w_{J}-\delta_{J} \\
x_{J, 2} \neq w_{J}+2 \delta_{J} \\
\delta_{J} \geqq 0
\end{array}\right\}
$$

を満足する $\delta_{J}$ が存在し, 式 (A.6), (A.7) より, 式 (A.8)

$$
\begin{aligned}
\Delta_{J}= & \Delta_{J}\left(\delta_{J}\right)=2\left(w_{J}-\delta_{J}\right) \ln \left(w_{J}-\delta_{J}\right) \\
& +\left(w_{J}+2 \delta_{J}\right) \ln \left(w_{J}+2 \delta_{J}\right)-3 w_{J} \ln w_{J} \quad(\mathrm{~A} .8)
\end{aligned}
$$

を得る。

$$
\begin{aligned}
& \quad \frac{d}{d \delta_{J}} \Delta_{J}\left(\delta_{J}\right)=2 \ln \left(\frac{w_{J}+2 \delta_{J}}{w_{J}-\delta_{J}}\right) \geqq 0 \quad\left(\because \delta_{J} \geqq 0\right) \\
& \text { かつ, } \Delta_{J}(0)=0 \text { となる。ゆえに, } \Delta_{J} \geqq 0 \text { となる。 } u_{J} \\
& \geqq x_{J, 2}(>0) \text { の場合, }
\end{aligned}
$$

$$
\left.\begin{array}{rl}
u_{J} & =w_{J}+\frac{\delta_{J}}{2} \\
x_{J, 2} & =w_{J}-\delta_{J} \\
\delta_{J} & \geqq 0
\end{array}\right\}
$$

を満足する $\delta_{J}$ が存在し, 式 (A.6), (A.9) より式 (A.10)

$$
\begin{aligned}
\Delta_{J}= & \Delta_{J}\left(\delta_{J}\right)=2\left(w_{J}+\frac{\delta_{J}}{2}\right) \ln \left(w_{J}+\frac{\delta_{J}}{2}\right) \\
& +\left(w_{J}-\delta_{J}\right) \ln \left(w_{J}-\delta_{J}\right)-3 w_{J} \ln w_{J}
\end{aligned}
$$

を得る。

$$
\frac{d}{d \delta_{J}} \Delta_{J}\left(\delta_{J}\right)=\ln \left(\frac{w_{J}+\delta_{J} / 2}{w_{J}-\delta_{J}}\right) \geqq 0 \quad\left(\because \delta_{J} \geqq 0\right)
$$

かつ, $\Delta_{J}(0)=0$ となる。したがって, $\Delta_{J} \geqq 0$ となる。 以上より, $u_{J} \leqq x_{J, 2}$ で $\Delta_{J} \geqq 0$ となり, 次式を得る。

$$
-\frac{\left(s_{Q}-s_{R}\right)}{R}=\sum_{J}^{n} \Delta_{J} \geqq 0
$$

$\therefore s_{Q} \leqq s_{R}$

等号は, $u_{J}=x_{J, 2}=w_{J}$ のとき, つまり, $x_{J, 1}=x_{J, 2}=$ $x_{J, 3}$ のとき成立する。

以上により不等式 (21) が了解されよう。

(昭和 49 年 7 月 25 日受理)

\section{文献}

1) M.H. Coleman, "Advances in Lipid Research", Vol. 1, Part 1, p. 31 (R. Paoletti and D. Kritchevsky, eds.), (1963) Academic Press, New York and London

2) M.H. Coleman, J. Amer. Oil Chem. Soc., 42, 1040 (1965)

3) A. Kuksis, "Progress in the Chemistry of Fats and Other Lipids", Vol. 12, Part 1, p. 143-145 (R.T. Holman, ed.), (1972) Pergamon Press, Oxford

4) P.M. Slakey, W.E.M. Lands, Lipids, 3, 30 (1968)

5) H. Brockerhoff, M. Yurkowski, J. Lipid Les., 7, 62 (1966)

6) 草野一化, 油化学, 8, 57 (1959)

7) 妹尾, “化学熱力学・I”, p. 107-118 (1971), 朝倉書店, 東京

8) 草野一仁, 油化学, 8, 8 (1959)

9) 草野一仁, 油化学, 8, 15 (1959) 